\title{
Lack of physiological suppression of circulating IGFBP-1 in puberty in patients with insulin-dependent diabetes mellitus
}

Päivi H Riihimaa, Mikael Knip ${ }^{2}$, Aimo Ruokonen ${ }^{1}$ and Päivi Tapanainen

Department of Pediatrics and ${ }^{1}$ Department of Clinical Chemistry, Oulu University Hospital, Oulu and ${ }^{2}$ Hospital for Children and Adolescents, University of Helsinki, Helsinki, Finland

(Correspondence should be addressed to Päivi H Riihimaa, Department of Pediatrics, University of Oulu, PO Box 5000, FIN-90014 University of Oulu, Oulu, Finland)

\begin{abstract}
Objective: To evaluate the interaction between serum free insulin, insulin-like binding protein (IGFBP)-1 and leptin concentrations during puberty in insulin-dependent diabetes mellitus (IDDM).

Design: Adolescent patients with IDDM $(n=101$, age $>9$ years, duration $>2$ years) from the Outpatient Clinic of the Department of Pediatrics at Oulu University Hospital, and non-diabetic controls, were recruited to the study. Free insulin, IGFBP-1, leptin and insulin antibody concentrations were measured from a fasting serum sample.

Results: Free insulin concentrations were lower in the patients than in the controls $(4.3 \pm 2.3 \mathrm{mU} / \mathrm{l} \mathrm{com-}$ pared with $6.5 \pm 3.1 \mathrm{mU} / \mathrm{l}, P<0.001$ ), and there was an inverse correlation between free insulin and fasting blood glucose in the boys with diabetes $(r=-0.53, P<0.001)$, whereas a positive correlation was observed between free insulin and leptin concentrations in the girls with diabetes $(r=0.30$, $P=0.020)$. The IGFBP-1 concentrations were greater in the patients than in the controls $(16.5 \pm 10.6 \mu \mathrm{g} / \mathrm{l}$ compared with $4.0 \pm 3.3, P<0.001)$, and they correlated significantly with blood glucose $(r=0.63, P<0.001)$ and free insulin $(r=-0.35, P<0.001)$. No significant difference was observed in the leptin concentrations between the patients and controls overall, despite greater total body fat in the girls with diabetes compared with the control girls.

Conclusions: Adolescents with IDDM are characterised by morning hypoinsulinaemia and high circulating IGFBP-1 concentrations, which may contribute to insulin resistance and impaired metabolic control during puberty. The mechanism behind the increased total body fat in the postpubertal female patients remains to be determined.
\end{abstract}

European Journal of Endocrinology 147 235-241

\section{Introduction}

Metabolic control in adolescent patients with insulindependent diabetes mellitus (IDDM) is influenced by deteriorating peripheral insulin sensitivity $(1,2)$ as a result of hormonal changes during puberty and relative hypoinsulinism in the hepatic portal circulation, whereas in healthy adolescents the increased insulin resistance is compensated by increased insulin secretion (3). The circulating concentrations of insulinlike growth factor binding protein (IGFBP)-1 decrease with advancing puberty in healthy adolescents, reflecting the physiological increase in biologically active insulin in the portal circulation (4), whereas adolescent patients with IDDM and with non-optimal glucose control have high serum IGFBP-1 concentrations concurrently with low free insulin concentrations, especially in the morning (5).

In addition to these changes induced by hypoinsulinism in IDDM, increasing proportions of body fat during puberty in girls with diabetes may affect the efficiency of biologically active insulin by inducing peripheral insulin resistance. Body fat and leptin concentrations increase during puberty in girls, whereas in boys the leptin concentrations decrease or remain stable in relation to fat-free mass $(6-9)$.

The majority of patients with insulin-treated diabetes still develop insulin antibodies in response to exogenous insulin, in spite of the extensive use of human insulin (10). As a consequence, the remaining free insulin represents the biologically active hormone in patients with insulin antibodies.

The present study focused on the interactions between serum free insulin, IGFBP-1, and leptin during puberty in adolescents with IDDM.

\section{Subjects and methods}

One hundred and one of 138 eligible patients with IDDM registered with the Outpatient Clinic at the Department of Pediatrics, Oulu University Hospital, 
Oulu, Finland, consented to take part in the study. The chronological age of the patients ranged from 9 to 18 years, and the duration of diabetes was more than 2 years. All the patients with IDDM who were younger than 15 years of age attended this outpatient clinic until the age of 16-18 years. One patient was excluded because of Down's syndrome and hypothyroidism. One hundred healthy age- and sex-matched control individuals were recruited from nearby schools. All the patients were receiving intensified insulin treatment, with three to four subcutaneous insulin injections per day. The characteristics of the patients and controls are shown in Table 1, and the study population has been described in detail previously (11). All the patients and controls and the parents of each gave an informed consent to the study, which was approved by the Ethics Committee of the Medical Faculty, University of Oulu, Oulu, and was carried out according to the provisions of the Declaration of Helsinki.

\section{Study design}

The Tanner pubertal stages were assessed by one of the investigators (PHR) during the initial clinical examination, by breast staging in the girls and genital staging in the boys (12). A testicular length $>20 \mathrm{~mm}$, or a volume of the larger testicle $>2.0 \mathrm{ml}$ [assessed as $0.52 \times$ length $(\mathrm{cm}) \times$ width squared $(\mathrm{cm})](13)$ was regarded as indicating the start of pubertal development in the boys. Height $(\mathrm{cm})$ was measured using a Harpenden stadiometer, and the mean of three separate, consecutive measurements was taken as the actual height. Weight $(\mathrm{kg})$ was measured on a digital weight scale with a precision of $0.1 \mathrm{~kg}$. Relative height for age (SDS) and relative weight for height (\%) were assessed from the Finnish growth charts (14).

The biceps, triceps and subscapular skin folds were assessed on the right side as described earlier (15), as the mean of three consecutive measurements performed with a Harpenden skinfold calliper. Body density was estimated with regression equations based on the triceps and subscapular skin folds (16), and the total body fat (\%) was calculated according to Keys \& Brožek (17).

\section{Laboratory methods}

A blood sample was obtained from the antecubital vein between 0700 and $0800 \mathrm{~h}$ after the individual had undergone an overnight fast, before the morning insulin injection and breakfast. The serum was stored at $-20{ }^{\circ} \mathrm{C}$ until required for analysis. The fasting blood glucose concentration $(\mathrm{mmol} / \mathrm{l})$ was measured with a bedside glucometer.

Serum free insulin concentrations Serum free insulin concentrations (mU/l) were quantified with an enzymelinked immunosorbent assay (DAKO Diagnostics Ltd, Ely, Cambridgeshire, UK) after pretreatment of the sample with polyethylene glycol to precipitate insulin-insulin antibody complexes. The sensitivity of the assay was $0.5 \mathrm{mU} / \mathrm{l}$ and the intra- and interassay coefficients of variation (CV) were less than $7.5 \%$ and $9.3 \%$ respectively. One girl with IDDM who exhibited a very

Table 1 Characteristics of the study participants. Values are means (S.D. or range).

\begin{tabular}{|c|c|c|}
\hline & Males & Females \\
\hline Patients/controls (No.) & $49 / 49$ & $51 / 51$ \\
\hline \multicolumn{3}{|l|}{ Age (years) } \\
\hline Patients & $13.59(1.83)$ & $13.65(2.23)$ \\
\hline Controls & $13.61(1.84)$ & $13.66(2.21)$ \\
\hline \multicolumn{3}{|l|}{ Height in relation to age (SDS) } \\
\hline Patients & $-0.07(0.88)$ & $0.15(0.99)$ \\
\hline Controls & $0.24(0.85)$ & $-0.08(0.78)$ \\
\hline Age at diabetes onset (years) & $6.52(3.47)$ & $6.81(3.36)$ \\
\hline Diabetes duration (years) & $7.08(2.22-15.33)$ & $6.88(2.14-15.62)$ \\
\hline Daily insulin dose (IU/kg per day) & $0.92(0.59-1.47)$ & $0.92(0.47-1.42)$ \\
\hline \multicolumn{3}{|l|}{$\begin{array}{l}\text { Fasting blood glucose }(\mathrm{mmol} / \mathrm{l}) \\
\text { at pubertal stages: }\end{array}$} \\
\hline Tanner I & $12.1(5.4)[n=11]$ & $10.1(4.8)[n=10]$ \\
\hline Tanner II & $8.7(3.2)[n=9]$ & $5.3(2.3)[n=4]$ \\
\hline Tanner III & $10.4(2.0)[n=4]$ & $15.8(3.0)[n=9]$ \\
\hline Tanner IV & $13.0(4.2)[n=11]$ & $11.3(4.6)[n=15]$ \\
\hline Tanner V & $12.2(3.8)[n=8]$ & $15.2(5.0)[n=9]$ \\
\hline \multirow{2}{*}{\multicolumn{3}{|c|}{$\begin{array}{l}\mathrm{HbA}_{1 \mathrm{c}}(\%) \\
\text { at pubertal s }\end{array}$}} \\
\hline & & \\
\hline Tanner I & $7.8(1.0)[n=15]$ & $7.8(1.3)[n=11]$ \\
\hline Tanner II & $7.6(1.0)[n=11]$ & $8.9(1.3)[n=4]$ \\
\hline Tanner III & $8.2(0.9)[n=4]$ & $8.9(1.1)[n=9]$ \\
\hline Tanner IV & $9.3(1.2)[n=11]$ & $8.8(1.7)[n=16]$ \\
\hline Tanner V & $8.4(1.5)[n=8]$ & $9.4(1.6)[n=11]$ \\
\hline
\end{tabular}


high insulin concentration $(45.1 \mathrm{mU} / \mathrm{l})$ was excluded from the analysis.

Insulin antibodies Insulin antibodies were analysed with a radiobinding microassay (18) modified from that described by Williams et al. (19). The cut-off limit for antibody positivity was set at the 99th percentile in 371 non-diabetic Finnish individuals (1.56 relative units (RU)). The intra-assay $\mathrm{CV}$ was $8.3 \%$ and the interassay CV $6.4 \%$ for a positive control sample with a medium antibody level.

Serum IGFBP-1 Serum IGFBP-1 concentrations ( $\mu \mathrm{g} / \mathrm{l})$ were measured with an immunoenzymometric assay (PP12 IEMA test, Medix Biochemica Oy, Kauniainen, Finland) having a sensitivity of $0.4 \mu \mathrm{g} / \mathrm{l}$. The intraassay $\mathrm{CV}$ was $2.5 \%$ at a serum concentration of $5.5 \mu \mathrm{g} / \mathrm{l}$ and the interassay CV $6.4 \%$ at a serum concentration of $4.8 \mu \mathrm{g} / \mathrm{l}$.

Serum leptin Serum leptin $(\mu \mathrm{g} / \mathrm{l})$ concentrations were quantified with a specific radioimmunoassay for human leptin (Linco Research Inc., St Charles, MO, USA). Intra- and interassay CVs were less than 5\% and $6 \%$ respectively, at serum concentrations of $7-$ $30 \mu \mathrm{g} / \mathrm{l}(20)$.

Glycated haemoglobin Glycated haemoglobin $\left(\mathrm{HbA}_{1 \mathrm{c}}\right)$ (\%) was measured with high-pressure liquid chromatography (non-diabetic range 4.0-6.0\%). Current $\mathrm{HbA}_{1 \mathrm{c}}$ was determined, and the mean of the $\mathrm{HbA}_{1 \mathrm{c}}$ values analysed at regular visits over the preceding 2 years (one to three measurements) was used as an indicator of long-term control.

\section{Statistical analysis}

The results are expressed as means \pm S.D. or range. Variables with skewed distribution were log-transformed, the differences between two means were evaluated with the unpaired Student's t-test, and the 95\% confidence interval (CI) for the difference between two means was determined. The leptin concentrations were adjusted for total body fat before the patients and controls were compared within various pubertal stages. Linear trends in variables in relation to pubertal maturation were assessed with one-way analysis of variance (ANOVA). Linear regression analysis was used for assessing correlations and to determine independent associations between variables. The statistical analyses were performed with SPSS 10.0 (SPSS Inc., Chicago, IL, USA).

\section{Results}

\section{Free insulin}

The serum free insulin concentrations were significantly lower in the patients than in the controls $(4.7 \pm 2.3 \mathrm{mU} / \mathrm{l}$ compared with $6.5 \pm 3.1 \mathrm{mU} / \mathrm{l}, 95 \% \mathrm{CI}$ -1.8 to -1.3$)$, and this was true for both the boys (3.9 $\pm 2.2 \mathrm{mU} / \mathrm{l}$ compared with $6.3 \pm 3.0 \mathrm{mU} / \mathrm{l}, 95 \% \mathrm{CI}$ -2.1 to -1.2$)$ and the girls $(4.6 \pm 2.3 \mathrm{mU} / \mathrm{l}$ compared with $6.7 \pm 3.2 \mathrm{mU} / 1,95 \% \mathrm{CI}-1.8$ to $-1.2 ; P<0.001$ for all). The free insulin concentrations were significantly lower in the patients than in the controls both before and after puberty (Fig. 1).
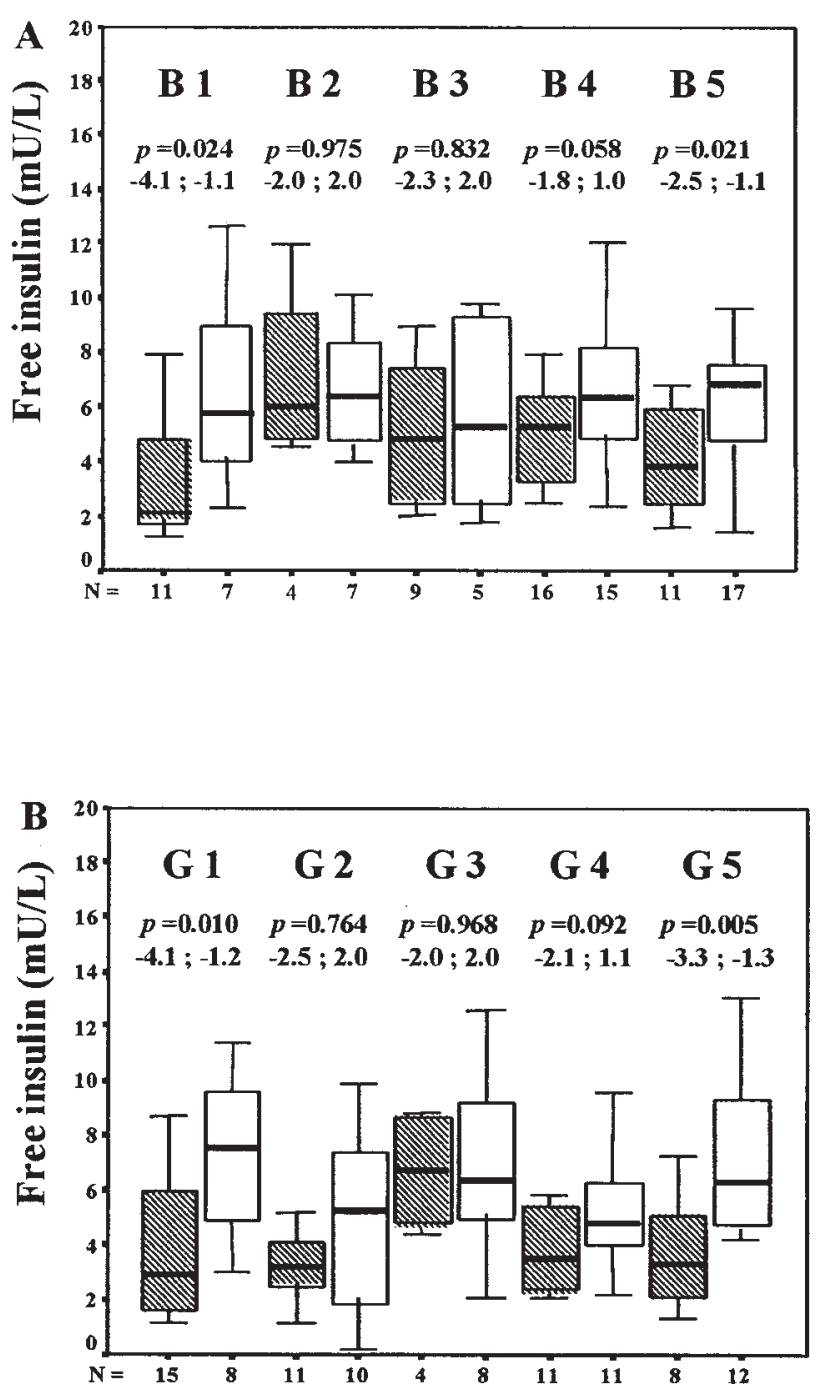

Figure 1 Serum free insulin concentrations in relation to pubertal maturation in (A) girls and (B) boys. B (breast stage in girls) and $G$ (genital maturation in boys) represent pubertal maturation according to Tanner pubertal staging. Shaded boxes, patients; open boxes, controls. Each box plot represents the median and the 25th and 50th centiles, and the whiskers represent the lowest and the highest values. The $95 \% \mathrm{Cl}$ of the difference between the means is shown under the $p$ value (Student's $t$-test). 


\section{IGFBP-1}

Serum IGFBP-1 concentrations were significantly greater in the patients than in the controls (16.5 $\pm 10.6 \mu \mathrm{g} / \mathrm{l}$ compared with $4.0 \pm 3.3 \mu \mathrm{g} / \mathrm{l}, 95 \%$ CI 3.6 to $5.6 ; P<0.001)$ and the concentrations were greater in the patients at each pubertal stage except at Tanner stage II in the girls (Fig. 2), whereas no significant difference in the IGFBP-1 concentrations was observed between girls and boys with diabetes $(P=0.07)$. The IGFBP-1 concentrations decreased with pubertal maturation in the controls $(F=63.1$; $P<0.001$, one-way ANOVA), whereas they remained high in the patients with IDDM $(F=3.9 ; P=0.051)$.
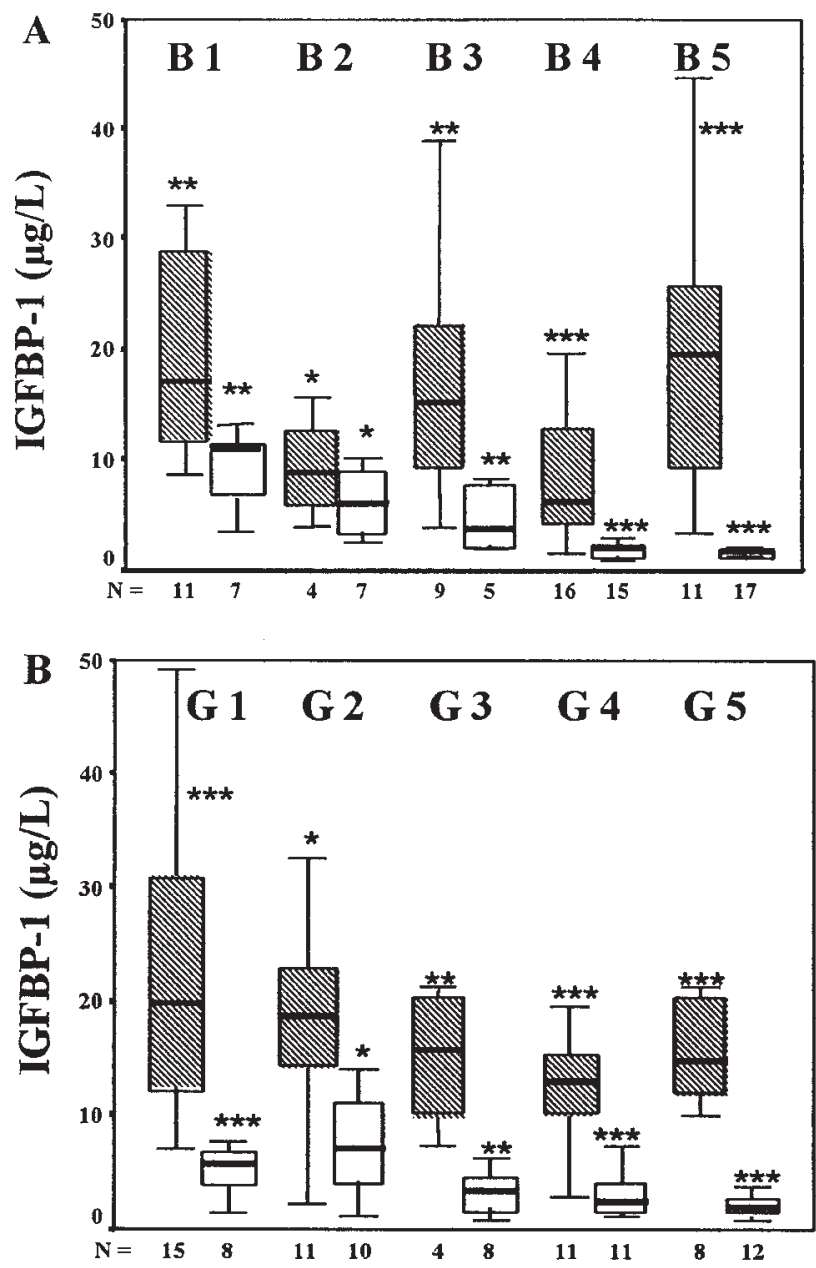

Figure 2 Serum IGFBP-1 concentrations in relation to pubertal maturation in (A) girls and (B) boys. $B$ (breast stage in girls) and $G$ (genital maturation in boys) represent pubertal maturation according to Tanner pubertal staging. Shaded boxes, patients; open boxes, controls. Each box plot represents the median and the 25th and 50th centiles, and the whiskers represent the lowest and the highest values. (A) ${ }^{*} P=0.269(95 \% \mathrm{Cl}-1.5$ to 3.4$)$, ${ }^{\star \star} P<0.01,{ }^{* \star \star} P<0.001$. (B) ${ }^{*} P=0.044$ (95\% Cl 1.0 to 5.3 ), ${ }^{\star \star} P<0.01,{ }^{\star \star \star} P<0.001$. (Student's $t$-test).

\section{Leptin}

Leptin concentrations were greater in the girls than in the boys, both among the patients $(14.5 \pm 6.0 \mu \mathrm{g} / \mathrm{l}$ compared with $7.0 \pm 4.3 \mu \mathrm{g} / \mathrm{l}, 95 \%$ CI 1.8 to 2.8 ; $P<0.001)$ and among the controls $(12.8 \pm 5.7 \mu \mathrm{g} / \mathrm{l}$ compared with $6.3 \pm 5.3 \mu \mathrm{g} / \mathrm{l}, 95 \%$ CI 1.9 to 3.1 ; $P<0.001$ ), whereas they did not differ significantly between the patients and controls overall $(P=0.08)$. The leptin concentrations within the pubertal stages are shown in Fig. 3. Serum leptin concentrations increased with pubertal maturation in the girls with diabetes $(F=19.1 ; P<0.001)$ and in the non-diabetic girls $(F=17.2 ; P<0.001)$, whereas they decreased in the boys with diabetes $(F=23.3 ; P<0.001)$ and in the control boys $(F=18.0 ; \quad P<0.001$, one-way ANOVA). By the end of puberty, total body fat was significantly greater in the girls with diabetes than in the control girls (Table 2).

\section{Insulin antibodies}

The median concentration of insulin antibodies was $96 \mathrm{RU}$ in the boys (mean $187 \mathrm{RU}$; range 1.0$1031 \mathrm{RU}$ ) and 108 RU in the girls (mean 200 RU; range 1.0-1941 RU). Twelve boys (26\%) and 13 girls $(25 \%)$ had a high insulin antibody concentrations $(>200 \mathrm{RU})$ and the proportion of those with high concentrations of insulin antibodies was comparable among the prepubertal (27\%), pubertal (24\%) and postpubertal $(26 \%)$ patients. The patients with high insulin antibody concentrations did not differ from those with insulin antibodies $<200 \mathrm{RU}$ with respect to serum free insulin concentration, age, diabetes duration, long-term $\mathrm{HbA}_{1 \mathrm{c}}$, age at disease presentation, or fasting blood glucose concentration.

\section{Correlations}

Free insulin concentrations correlated significantly with the daily insulin dose in the girls $(r=0.42$, $P=0.002)$, but not in the boys $(r=-0.006$, $P=0.97)$, whereas they were inversely related to fasting blood glucose in the boys with diabetes $(\mathrm{r}=-0.53$, $P<0.001)$ and positively related to $\mathrm{HbA}_{1 \mathrm{c}}(r=0.37$, $P=0.005)$ and leptin concentrations $(r=0.30$, $P=0.020)$ in the girls with diabetes.

IGFBP-1 concentrations correlated significantly with blood glucose $(r=0.63, P<0.001)$ and free insulin $(r=-0.35, P<0.001)$ in the entire group of patients. They correlated with leptin concentrations in the control girls $(r=-0.65, P<0.001)$, but no significant correlation was observed in the girls or in the boys with diabetes or in the control boys. 

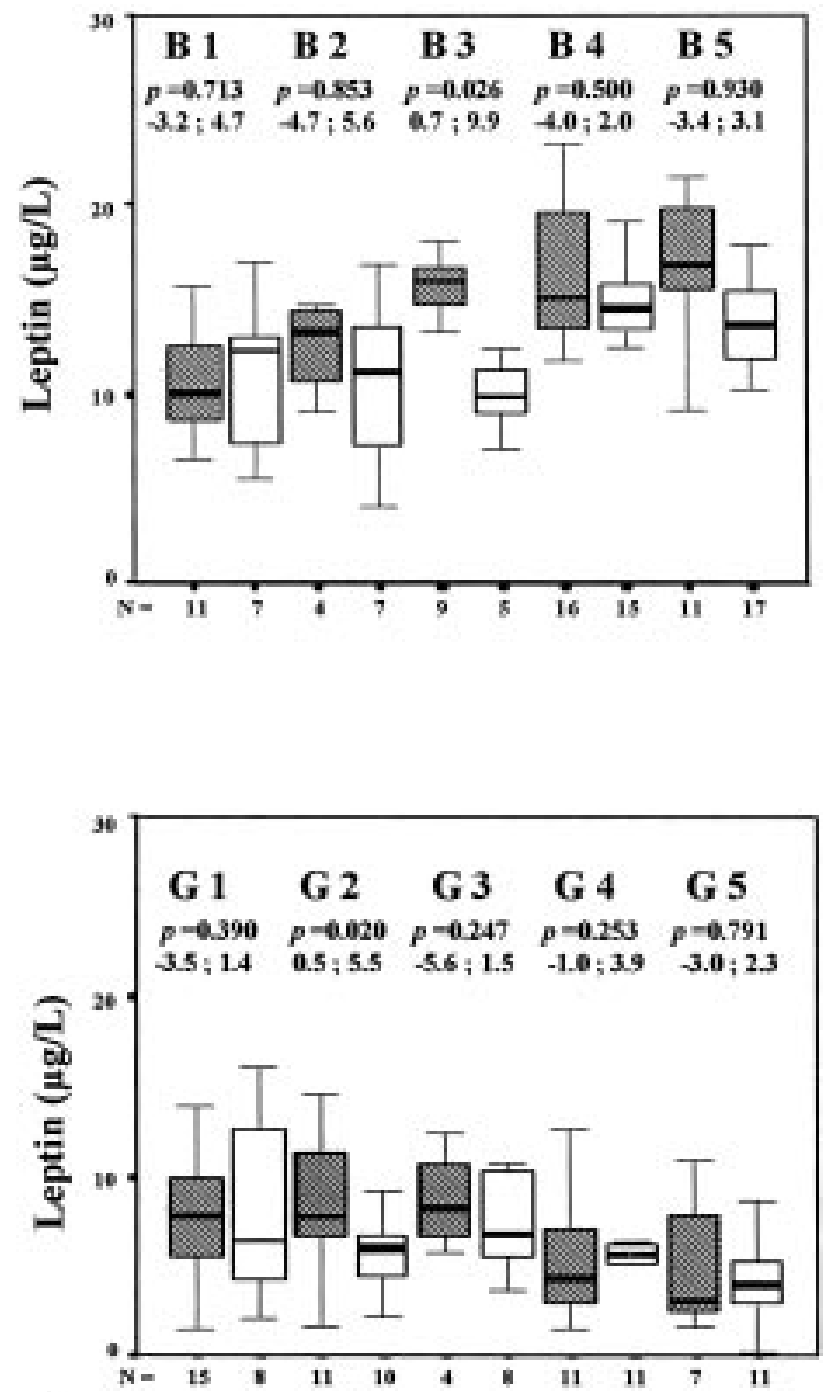

Figure 3 Serum leptin concentrations, adjusted for total body fat, in relation to pubertal maturation in (A) girls and $(B)$ boys. $B$ (breast stage in girls) and $\mathrm{G}$ (genital maturation in boys) represent pubertal maturation according to Tanner pubertal staging. Shaded boxes, patients; open boxes, controls. Each box plot represents the median and the 25th and 50th centiles, and the whiskers represent the lowest and the highest values. The $95 \% \mathrm{Cl}$ of the difference between the means is shown under the $p$ value (Student's $t$-test).

\section{Discussion}

High fasting IGFBP-1 concentrations were demonstrated in young patients with IDDM at each pubertal stage, whereas peripheral insulin concentrations were lower than in healthy adolescents, the lowest concentrations being observed in prepubertal and postpubertal patients.

IGFBP-1 concentrations decrease in healthy adolescents as puberty advances, reflecting increasing insulin concentrations (21), whereas patients with IDDM have high hepatic IGFBP-1 production induced by portal hypoinsulinaemia. As in healthy individuals, in patients with IDDM the circulating IGFBP-1 concentrations have a diurnal variation, with maximum values during the night and morning, and the highest concentrations seen in the presence of low insulin concentrations (22). As the fasting serum IGFBP-1 concentrations correlate well with 24-h mean values in adults with and without IDDM (22), it might be assumed that high IGFBP-1 concentrations in the present study reflected the concentrations during the previous night and early morning. High IGFBP-1 and low free insulin concentrations have been observed during puberty in diabetes, in spite of therapeutic administration of insulin (23); this, together with the observations of high IGFBP-1 in association with the dawn phenomenon in adolescent patients (24), is consistent with the present observations.

Serum free insulin was related to the daily insulin dose in girls with diabetes, but not in boys with diabetes. This, together with the inverse association of free insulin with fasting blood glucose in the present study, might support the assumption of an insufficient subcutaneous insulin supply in the adolescent boys with diabetes. In healthy pubertal adolescents, insulin resistance is restricted to the peripheral tissues, and he physiological insulin supply in the portal blood is sufficient to prevent hepatic glucose overproduction (3), whereas the obvious lack of insulin in adolescent patients leads to redundant hepatic glucose production and thereby to increased peripheral insulin resistance.

Serum leptin concentrations increased in the girls and decreased in the boys, along with pubertal

Table 2 Total body fat (\%) in relation to pubertal maturation. Values are means (25th and 75 th percentile).

\begin{tabular}{lccccc}
\hline & \multicolumn{5}{c}{ Tanner pubertal stage } \\
\cline { 2 - 6 } & T I & T II & T III & T IV & T V \\
\hline Males & & & & \\
$\quad$ Patients & $17.7(15.0,20.2)$ & $17.1(13.9,19.3)$ & $16.0(13.5,19.0)$ & $12.1(9.7,14.6)$ & $11.6(8.9,15.4)$ \\
$\quad$ Controls & $18.1(14.2,24.0)$ & $15.7(14.1,17.0)$ & $18.5(14.9,20.2)$ & $13.1(12.3,13.3)$ & $11.1(8.3,12.5)$ \\
Females & & & & & \\
$\quad$ Patients & $21.0(18.6,23.3)$ & $20.5(17.7,22.6)$ & $22.3(21.6,24.4)$ & $23.4(20.5,27.3)$ & $24.5(21.7,28.2)^{*}$ \\
$\quad$ Controls & $21.0(16.5,23.4)$ & $20.5(16.4,24.7)$ & $19.6(17.7,21.5)$ & $22.1(20.6,23.6)$ & $21.1(19.0,23.0)$ \\
\hline
\end{tabular}

${ }^{*} P=0.008(95 \% \mathrm{Cl} 1.0$ to 5.8 for the difference between the means) compared with the control girls at pubertal stage Tanner $\mathrm{V}$. 
maturation and in parallel with the changes observed in total body fat. This finding is in agreement with those of a previous follow-up study (9) and with some cross-sectional surveys $(6,7,25,26)$ involving young patients with IDDM and healthy adolescents. However, total circulating leptin concentrations were lower in the present patients than in the healthy adolescents, in contrast to some previous reports $(6,9)$. In spite of a significantly increased proportion of body fat by the end of puberty, the girls with IDDM in the present study had serum leptin concentrations similar to those seen in the non-diabetic girls. This suggests that factors other than hyperleptinaemia are responsible for the accumulation of fat tissue in young females with IDDM. Although it has been speculated that repetitive hyperinsulinaemia developing in association with repeated insulin injections may stimulate the synthesis of leptin (6), no change in leptin concentrations was observed in a hyperinsulinaemic clamp study of adult men with IDDM (27). The decrease in leptin concentrations with advancing puberty in the present male participants may be explained by a reduction in total fat, or an increase in fat-free mass (9), changes in androgen secretion, or low circulating concentrations of free insulin.

The present observations show that adolescents with IDDM do not experience the physiological decrease in circulating IGFBP-1 concentrations during puberty that are seen in healthy adolescents. Early morning hypoinsulinaemia is related to high IGFBP-1 concentrations, and presumably the relatively low leptin concentrations also reflect low insulin supply in the patients. The increased IGFBP-1 concentrations may reduce the local effects of IGF-I (28), and because IGF-I plays an important part in the feedback regulation of growth hormone, a reduced IGF-I effect might lead to increased secretion of growth hormone in pubertal individuals with IDDM (29). Sustained secretion of growth hormone has been implicated in the development of insulin resistance and poor metabolic control in adolescents with IDDM. Suppression of the IGFBP-1 concentrations would require adequate insulin concentrations in the portal circulation, which can not easily be achieved with the present modes of insulin replacement therapy.

\section{Acknowledgements}

We thank Ms Riitta Päkkilä and Ms Sirpa Anttila for their skilful technical assistance. This work was supported by grants from the Alma and K A Snellman Foundation (Oulu, Finland), the Foundation for Pediatric Research (Oulu, Finland), the Medical Research Fund, Oulu University Hospital (Oulu, Finland) and the Maud Kuistila Foundation (Helsinki, Finland).

\section{References}

1 Amiel SA, Sherwin RS, Simonson DC, Lauritano AA \& Tamborlane WV. Impaired insulin action in puberty: a contributing factor to poor glycaemic control in adolescents with diabetes. New England Journal of Medicine 1986315 215-219.

2 Bloch CA, Clemons P \& Sperling M. Puberty decreases insulin sensitivity. Journal of Pediatrics $1987110481-487$.

3 Amiel SA, Caprio S, Sherwin RS, Plewe G, Haymond MW \& Tamborlane WV. Insulin resistance of puberty: a defect restricted to peripheral glucose metabolism. Journal of Clinical Endocrinology and Metabolism 199172 277-282.

4 Holly JMP, Dunger DB, Edge JA, Smith CP, Chard T \& Wass JAH. Insulin-like growth factor binding protein-1 levels in diabetic adolescents and their relationship to metabolic control. Diabetic Medicine 19907 618-623.

5 Batch JA, Baxter RC \& Werther G. Abnormal regulation of insulinlike growth factor binding proteins in adolescents with insulindependent diabetes. Journal of Clinical Endocrinology and Metabolism $199173964-968$

6 Kiess W, Anil M, Blum WF, Englaro P, Juul A, Attanasio A et al. Serum leptin levels in children and adolescents with insulindependent diabetes mellitus in relation to metabolic control and body mass index. European Journal of Endocrinology 1998138 501-509.

7 Verrotti A, Basciani F, Morgese G \& Chiarelli F. Leptin levels in non-obese and obese children and young adults with Type 1 diabetes mellitus. European Journal of Endocrinology 1998139 $49-53$.

8 Luna R, Carcia-Mayor V, Lage M, Andrade MA, Barreiro J, Pombo $M$ et al. High serum leptin levels in children with Type 1 diabetes mellitus: contribution to age, BMI, pubertal development and metabolic status. Clinical Endocrinology 199951 603-610.

9 Ahmed ML, Ong KKL, Watts AP, Morrell DJ, Preece MA \& Dunger DB. Elevated leptin levels are associated with excess gains in fat mass in girls, but not boys, with Type 1 diabetes: longitudinal study during adolescence. Journal of Clinical Endocrinology and Metabolism $2001861188-1193$.

10 Van Haeften TW. Clinical significance of insulin antibodies in insulin-treated diabetic patients. Diabetes Care $1989 \mathbf{1 2}$ 641-648.

11 Riihimaa PH, Knip M, Hirvelä H \& Tapanainen P. Metabolic characteristics and urine albumin excretion rate in relation to pubertal maturation in type 1 diabetes. Diabetes/Metabolism Research and Reviews 200016 269-275.

12 Tanner JM. The development of the reproductive system. In Growth at Adolescence, edn 2, ch 2, pp 28-39. Oxford: Blackwell Scientific Publications, 1962.

13 Hansen PF \& With TK. Clinical measurement of testes in boys and men. Acta Medica Scandinavica Supplementum $1952 \mathbf{2 6 6}$ 457-465.

14 Sorva R, Perheentupa J \& Tolppanen EM. A novel format for a growth chart. Acta Pediatrica Scandinavica 198473 527-529.

15 Owen GM. Measurement, recording, and assessment of skinfold thickness in childhood and adolescence: report of a small meeting. American Journal of Clinical Nutrition 198235 629-638.

16 Parizkova J. Total body fat and skinfold thickness in children. Metabolism 196110 794-807.

17 Keys A \& Brožek J. Body fat in adult man. Physiological Reviews $195333245-352$.

18 Ronkainen MS, Hämäläinen AM, Koskela P, Åkerblom HK \& Knip M. Pregnancy induces nonimmunoglobulin insulin-binding activity in both maternal and cord blood serum. Clinical and Experimental Immunology $2001 \mathbf{1 2 4}$ 190-196.

19 Williams AJK, Bingley PJ, Bonifacio E, Palmer JP \& Gale EAM. A novel micro-assay for insulin autoantibodies. Journal of Autoimmunity 199710 473-478.

20 Ma Z, Gingerich RL, Santiago JV, Klein S, Smith CH \& Landt M. Radioimmunoassay of leptin in human plasma. Clinical Chemistry $199642942-946$. 
21 Holly JMP, Smith CP, Dunger DB, Howell RJS, Chard T, Perry LA et al. Relationship between the pubertal fall in sex hormone binding globulin and insulin-like growth factor binding proteinI. A synchronized approach to pubertal development? Clinical Endocrinology $198931277-284$.

22 Hilding A, Brismar K, Degerblad M, Thoren M \& Hall K. Altered relation between circulating levels of insulin-like growth factorbinding protein-1 and insulin in growth hormone-deficient patients and insulin-dependent diabetic patients compared to that in healthy subjects. Journal of Clinical Endocrinology and Metabolism $1995 \mathbf{8 0} 2646-2652$.

23 Muñoz MT, Barrios V, Pozo J \& Argente J. Insulin-like growth factor I, its binding proteins 1 and 3, and growth hormonebinding protein in children and adolescents with insulin-dependent diabetes mellitus: clinical implications. Pediatric Research $199639992-998$.

24 Kobayashi K, Amemiya S, Sawanobori E, Higashida K, Ishihara T, Kobayashi $\mathrm{K}$ et al. Role of IGF binding protein-1 in the dawn phenomenon and glycemic control in children and adolescents with IDDM. Diabetes Care 199720 1442-1447.

25 Carlsson B, Ankarberg C, Rosberg S, Norjavaara E, AlbertssonWikland K \& Carlsson LMS. Serum leptin concentrations in relation to pubertal development. Archives of Disease in Childhood $199777396-400$.
26 Garcia-Mayor RV, Andrade MA, Rios M, Lage M, Dieguez C \& Casanueva FF. Serum leptin levels in normal children: relationship to age, gender, body mass index, pituitary-gonadal hormones, and pubertal stage. Journal of Clinical Endocrinology and Metabolism $1997 \mathbf{8 2} 2849-2855$.

27 Tuominen JA, Ebeling P, Stenman U-H, Heiman ML, Stephens TW \& Koivisto VA. Leptin synthesis is resistant to acute effects of insulin in insulin-dependent diabetes mellitus patients. Journal of Clinical Endocrinology and Metabolism 199782 381-382.

28 Taylor AM, Dunger DB, Preece MA, Holly JM, Smith CP, Wass JA et al. The growth hormone independent insulin-like growth factor-1 binding protein BP-28 is associated with serum insulin-like growth factor-1 inhibitory bioactivity in adolescent insulin-dependent diabetics. Clinical Endocrinology 199032 229-239.

29 Dunger DB \& Cheetham TD. Growth hormone insulin-like growth factor I axis in insulin-dependent diabetes mellitus. Hormone Research $1996462-6$.

Received 29 November 2001

Accepted 17 April 2002 